\title{
EFEKTIFITAS PEMBELAJARAN MASA PANDEMI DALAM MENINGKATKAN KOMPETENSI SISWA MELALUI DALUTA
}

\author{
JADIAMAN SIPAYUNG \\ SMAN Gunung Meriah \\ Email : sipayung.jadiaman23@gmail.com
}

\begin{abstract}
ABSTRAK
Tujuan dari penelitian ini untuk memberikan alternatif dan solusi bagi Pemerintah, Pengawas sekolah, Kepala Sekolah, dan Guru dalam pembelajaran Masa Pandemi Covid-19 melalui DALUTA yaitu pembelajaran yang dilaksanakan disekolah dengan Daring, Luring dan Tatap Muka Terbatas. Pembelajaran daring dilaksanakan melalui, whatsapp group, Video call, Google classroom. Pembelajaran Luring, dimana anak-anak mengambil tugas ke sekolah dan mengembalikannya secara terjadwal, Pembelajaran ini dikombinasikan antara tatap muka terbatas/Bergelombang dengan memenuhi standar Protokol Kesehatan. Pembelajaran bergelombang dilaksanakan dilaksanakan satu hari dua gelombang dengan tidak ada istirahat. Pembelajaran DALUTA menjadi bermakna, semangat belajar semakin meningkat, tugas-tugas dikerjakan dan tujuan pembelajaran tercapai.
\end{abstract}

Kata Kunci : Pembelajaran Daring, Luring dan Tatap Muka Terbatas

\section{PENDAHULUAN}

Dalam pendidikan mengalami perubahan mendasar.Pembelajaran yang selama ini dilaksanakan di dalam kelas dilaksanakan dengan pembelajaran jarak jauh (PJJ) atau Daring. Nadiem Makarim mengeluarkan Permendikbud no:4 tahun 2020 yang mengatur proses belajar dari rumah yang dilaksanakan melalui daring.Pembelajaran dilaksanakan dari rumah (Work From Home ) melalui jaringan internet. Dari pembelajaran jarak jauh yang sebelumnya kita laksanakan ada dampak yang cukup besar dirasakan oleh guru yaitu Learning loss atau hilangnya minat belajar pada peserta didik. (https://tinyurl.com/2dtaa3u2).

Menurut Suciyati mengatakan, minat belajar merupakan Ketertarikan atau kecendrungan melakukan suatu kegiatan untuk memperoleh suatu pengetahuan atau perubahan perilaku sebagai hasil pengalamanya sendiri (Suciati.2018).Sedangkan Rahmadani berpendapat bahwa minat yang rendah menyebabkan kesulitan belajar pada diri seseorang (Ramadani, 2017)

Minat belajar siswa menurun drastis dapat dilihat dari tugas-tugas yang diberikan Bapak/Ibu Guru melalui melalui WA Group.Pembelajaran yang dilaksanakan melalui melalui WA group dengan membuat tugas,dimana tugas yang diberikan Guru selama ini tidak dikerjakan sebagaimana mestinya.Hampir lima puluh persen siswa tidak mengerjakan tugasnya.

Masa Pandemi ini membuat guru dan peserta didik kurang dalam intensitas interaksi saat proses pembelajaran.Akibatnya tujuan pembelajaran belum tercapai. Kurang efektifnya pembelajaran daring menurut peserta didik dapat disebabkan oleh perubahan sistem belajar yang sebelumnya konvensional menjadi sistem daring dengan sangat mendadak tanpa adanya persiapan matang sehingga banyak kendala yang dijumpai selama masa adaptasi (Hidayah dkk., 2020)

Pembelajaran yang dilaksanakan secara Daring ini kurang efektif dilaksanakan. Beberapa murid-murid tidak mengerjakan tugasnya dengan berbagai alasan :

1. Internet

Dalam pembelajaran daring ini dimana para orangtua dipaksa memiliki HP android dan isi paket.Pembelian paket ini sering menjadi masalah karena situasi ekonomi rakyat yang lemah masa virus corona-19. Mengingat harga paket internet tidak murah terlebih dalam pandemic Covid 19 roda perekonomian berjalan melambat. Daerah ini berdekatan dengan pegunungan mengakibatkan sinyal kurang baik,apalagi jaringan listrik padam,maka sinyal tidak ada. Selain itu koneksi internet yang lambat membuat sering telat dalam mengumpulkan tugas. Kalaupun 


\section{EDUTECH : Jurnal Inovasi Pendidikan Berbantuan Teknologi \\ Vol. 1 No. 2 Agustus 2021, e-ISSN : 2797-0140 | p-ISSN : 2797-0590}

ada yang menggunakan jaringan seluler terkadang jaringan yang tidak stabil, karena letak geografis yang masih jauh dari jangkauan sinyal seluler. Hal ini juga menjadi permasalahan yang banyak terjadi pada peserta didik yang mengikuti pembelajaran daring, sehingga pelaksanaannya kurang efektif (Kemdikbud, 2020).

2. Kurang paham Materi Pembelajaran

Materi yang diberikan Bapak/Ibu Guru belum seluruhnya dipahami oleh siswa.Banyak siswa meminta penjelasan tentang materi yang diberikan. Mereka memahami berdasarkan tafsiran atau sudut pandang mereka sendiri. Hal ini terbukti dari pengalaman di lapangan, banyak sesuai yang meminta penjelasan lebih lanjut terhadap materi yang disajikan secara daring melalui chatting whatshapp atau menelepon langsung kepada guru.

3. Ketidaksiapan Guru

Pembelajaran selama ini dilaksanakan dengan tatap muka dimana guru menjelaskan pembelajaran di kelas.Pembelajaran daring mengharuskan Guru membuat power powint,vidio pembelajaran dll.Guru yang kurang paham teknologi pembelajaran tidak menarik.Guru hanya memberikan tugas dan dikerjakan ,kemudian dikumpulkan melalui WA group. Mereka tidak mampu mengakses lebih jauh yang berkaitan dengan jaringan internet, menggunakan berbagai aplikasi pembelajaran, membuat media/video pembalajaran sendiri dan sebagainya. Asmuni (2020). Dari Peristiwa ini penulis menawarkan Pembelajaran DALUTA. Pembelajaran disekolah dilaksanakan dengan menggabungkan pembelajaran Daring, Luring dan Pembelajaran Tatap Muka ( PTM) terbatas sebagai solusi dari permasalahan tersebut.

\section{METODE PELAKSANAAN}

Pendampingan tatap Muka dimana pengawas secara langsung memahami sejauhmana kinerja Guru dan melakukan pendampingan dalam meningkat kinerja.Kolabolasi Pengawas dan Guru lebih efektif digunakan. Pembelajaran Efektif merupakan proses pembelajaran yang mencapai tujuan pengajaran.Proses pembelajaran bersifat tingkat tinggi.Proses pembelajaran efektif ini penting dipahami agar kinerja kita sebagai Guru Bermartabat.

Lantas, bagaimana caranya siswa atau mahasiswa dapat belajar daring dengan efektif?

- Komunikasi antar tenaga pengajar dan murid atau mahasiswa harus berjalan dengan baik pada saat melakukan video call.

- Aktif dalam berdiskusi baik dengan tenaga pengajar atau teman-teman.

- Managemen waktu bagi para siswa atau mahasiswa sangat penting. Meski belajar di rumah, pastikan kamu membuat catatan mana saja tugas yang sudah dikerjakan, dan mana tugas yang harus segera kamu selesaikan.

- Jangan lupa untuk tetap bersosialisasi dengan orang lain, termasuk anggota keluarga di rumah, serta teman-teman sekelas di luar sesi video call untuk mengasah kemampuan bersosialisasimu.

Namun sosialisasi yang terjadi antar teman ,sering diluar pembelajaran.Pembahasan yang dibahas terkait berita-berita masa kini yang kurang berhubungan dengan proses Pembelajaran. Pembelajaran yang dibuat oleh Guru sering abai ,yang tidak tepat dikumpulkan pada waktunnya.Bahkan ada pemahaman dari siswa tidak mengerjakan tugas tidak menjadi masalah. Pembelajaran melalui tatap Muka dimana pembelajaran yang menghadirkan Guru dan siswa dalam tempat yang sama.Pembelajaran menjadi terpogram dan terjadwal serta tujuanpun lebih mudah tercapai.

Direktur Jenderal Pendidikan Anak Usia Dini, Pendidikan Dasar, dan Pendidikan Menengah (Dirjen Paudasmen) Kemendikbud Ristek Jumeri mengatakan, pandemi Covid-19 tidak boleh menghalangi sekolah menyelenggarakan PTM di daerah yang masih aman. Daerah jalur kuning dan hijau tetap dimungkinkan untuk pembelajaran tatap Muka terbatas Dari penjelasan diatas dimungkinkan Pembelajaran Tatap muka terbatas bagi daerah -daerah tertentu yaitu jalur hijau dan kuning. Daerah Gunung Meriah merupakan salah satu daerah yang dianggap berada pada kategori jalur Hijau. Sampai tulisan ini di selesaikan belum ada sepengetahuan penulis terdeteksi terpapar covid-19. SMAS Bina Bangsa dan Satu Padu 
Boarding School berada di STM Hilir berbatasan dengan Kecamatan Gunung Meriah. Atas kesepakatan dengan pimpinan sekolah kami mencoba dengan melaksanakan tatap muka terbatas, tetapi dengan protokol kesehatan yang ketat. Untuk kegiatan pembelajaran di luar lingkungan sekolah diperbolehkan dengan protokol kesehatan yang ketat.

\section{HASIL DAN PEMBAHASAN}

Pembelajaran yang dilaksanakan secara DALUTA membawa perubahan yang signifikan dalam pembelajaran siswa.Dari 145 siswa SMAN Gunung Meriah ,seluruhnya melaksanakan pembelajaran dengan baik.Belajar anak semakin tertib dan terkendali. Anak semakin disiplin dan berkarakter yang baik.

\section{A. Pembelajaran Daring}

Pada umumnya pembelajaran daring dilaksanakan melalui WA Group dan membentuk Google classroom.Guru-guru memberikan tugas dan dikerjakan oleh siswa dalam waktu tertentu.Hanya sebagian kecil menggunakan vidio pembelajaran.Pada waktu tententu seorang siswa bernama Wahyudi bercerita pada penulis yang mengatakan : Tugas tidak dikerjakan ,tidak apa-apa.Prilaku siswa ini berulang dan semakin banyak berulang.Maka saat tatap muka siswa ini akan diproses dan diberikan pembinaan.

Berdasarkan laporan semester akhir Desember 2020 Hampir 50 persen anak tidak menerima Raport karena tidak mengerjakan tugas bahkan ujian semester. Sekolah menahan Raport siswa sebagai sanksi karena belum menerjakan tugasnya.Dari 145 siswa yang menyelesaikan tugasnya dengan baik 75 orang,sementara 70 orang belum mengerjakan tugasnya.

\section{B. Luring}

Pembelajaran tatap muka dimana para siswa/Orang mengambil tugas ke sekolah.Besoknya tugas yang dikerjakan siswa dikumpulkan dan begitulah secara berkelanjutan. Semua sekolah binaan penulis melaksanakannya.

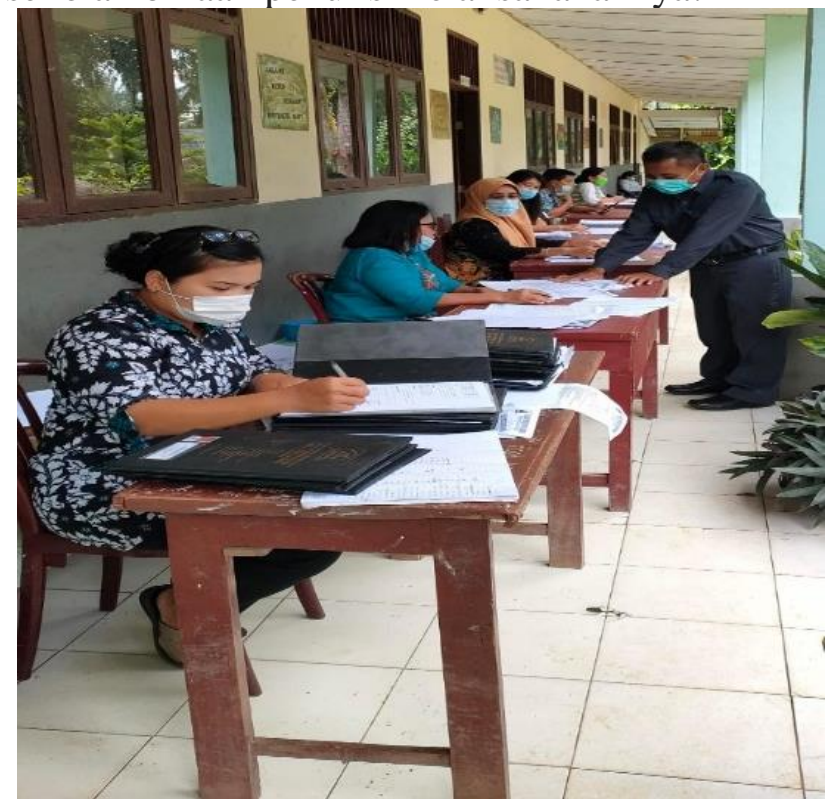

\section{Gambar 1.Guru-Guru berada di depan kelas menerima dan memeriksa Tugas-Tugas} siswa

Para Guru-Guru SMAS Bina bangsa mengangkat meja didepan kelas yang akan menerima tugas tugas siswa dan memeriksanya. Setelah dikoreksi Guru ,maka dikembalikan pada siswa dan dilaksanakan berkelanjutan.Dengan cara seperti ini maka agak sulit bagi siswa untuk tidak mengerjakan tugas.Pembelajaran yang belum dipahami siswa bisa dikonsultasikan disini. 
C. Pembelajaran Tatap Muka ( PTM ) Terbatas

Pembelajaran Tatap Muka Terbatas (PTM) dengan beberapa catatan yang diterapkan yaitu:

a. Sekolah memenuhi syarat-syarat prokes

Protokol kesehatan standar di antaranya yaitu penyedian alat test suhu badan, cuci tangan/ hand sanitizer, jaga jarak. Prokes $3 \mathrm{M}$ diterapkan dengan disiplin ketat dan penuh kehati-hatian. Ruangan tidak menggunakan AC, karena ruangan AC mengakibatkan peningkatan pertumbuhan dan perberkembangan Covid-19.

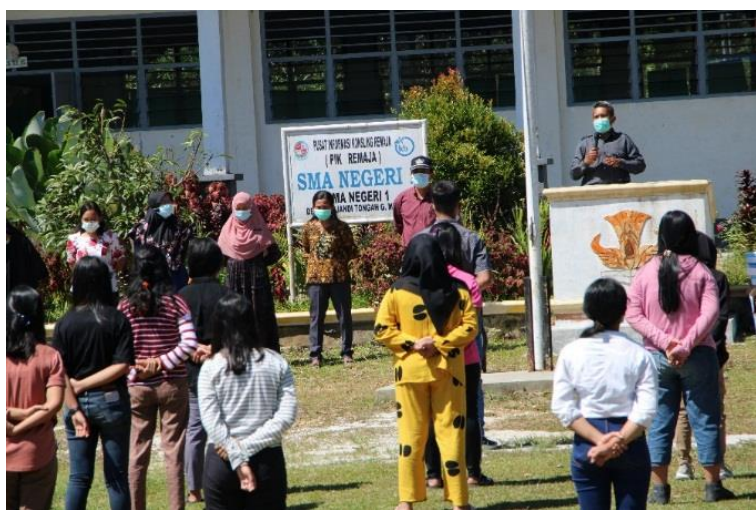

\section{Gambar 3.Bimbingan terhadap Guru-Guru dan Siswa}

Penulis melaksanakan bimbingan terhadap Guru dan siswa.Kepada para siswa dan Guru penulis tekankan supaya jaga ketat protokol kesehatan.Kepada Bapak Ibu Guru dan siswa mengatakan masa-masa sulit ,untuk perlu disikapi dan diharapkan bagi kita untuk berpikir lebih eksta dan penuh kehatihatian.Pembelajaran tetap ada walaupun masa pandemi.Kepada para siswa dikatakan Supaya semangat belajar semakin tinggi dan jangan tergantung guru,banyak belajar dari Google. Bapak Ibu/Guru diharapkan supaya membuat inovasi inovasi pembelajaran.Pembelajaran yang dibuat oleh Guru Menarik,Menantang dan Merangsang semangat belajar siswa

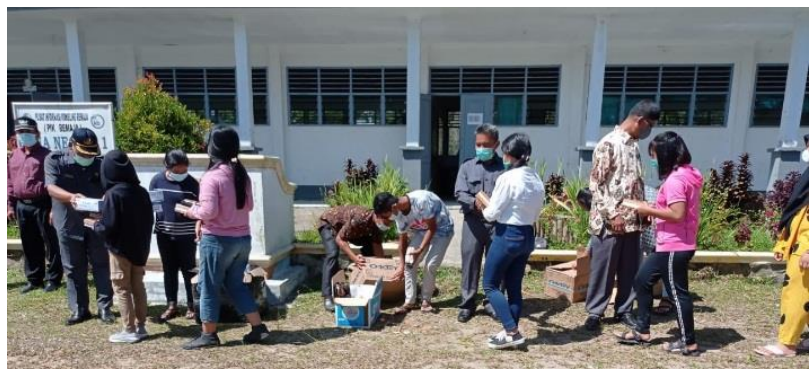

Gambar 4. Penulis beserta Pimpinan sekolah membagikan masker kepada Siswa.

Penulis beserta Kepala sekolah dan Guru -guru membagikan masker kepada para siswa, sebagai salah satu sarat untuk dapat mengikuti pembelajaran tatap muka terbatas.Apabila siswa tidak memakai masker maka mereka akan di pulangkan.

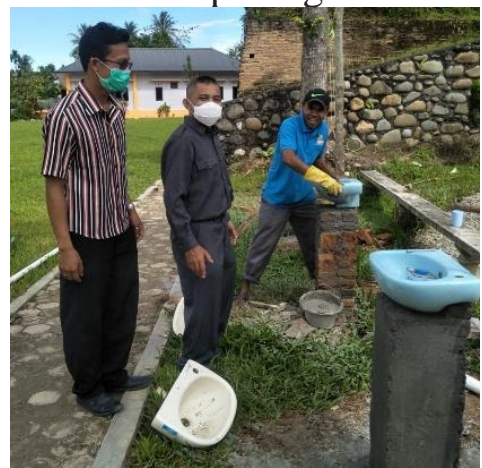




\section{Gambar 5.Penulis beserta dengan staf sekolah dan pekerja}

Penulis sedang menyaksikan pengerjaan pembuatan cuci tangan sebagai salah satu syarat protokol kesehatan.

\section{b. Menggunakan pembelajaran bergelombang}

Selama ini satu kelas untuk SD adalah 28 orang. Siswa dibagi dua tahap menjadi 14 orang untuk setiap gelombangnya. Sedangkan untuk SMP yang berjumlah 32 orang dibagi dua gelombang menjadi 16 orang saja untuk setiap gelombang. Untuk SMA yang berjumlah 36 orang setiap kelas dibagi dua tahap hanya 18 orang saja pergelombang. Cara seperti ini bisa memenuhi standar protokol kesehatan. Dalam Pembelajaran normal biasanya satu bangku dua orang ,dalam pembelajaran masa pandemi kami terapkan denngan satu bangku satu orang sesuai dengan standart protokol kesehatan.

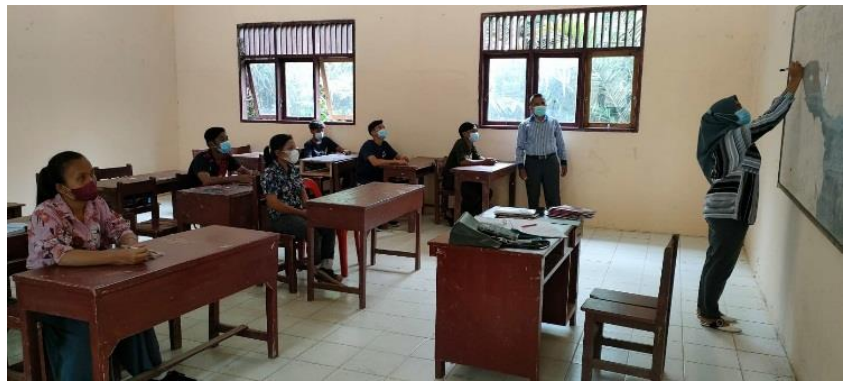

Gambar 7. Gambar ini menunjukkan pembelajaran di kelas yang mematuhi prokes

Dari gambar ini dapat dilihat pembelajaran di kelas sesuai prokes.satu bangku satu orang.Pembelajaran dibuat dengan waktu terbatas.Dalam satu hari pembelajaran disekolah dibagi atas 3 gelombang.Satu gelombang siswa sekitar satu setengah jam dengan menerima materi dari beberapa Guru.Seorang guru memberikan materi pembelajaran lebih kurang 15 menit ,selanjutnnya di isi oleh Guru berikutnya secara bergiliran.Selesai gelombang pertama langsung pulang dan masuk gelombang berikutnya.

\section{c. Skala prioritas penyajian materi}

Dilakukan pemilahan materi pelajaran. Materi yang diajarkan yang dianggap prioritas dan penting yang memuat hal-hal pokok dan sangat dibutuhkan anak dalam kehidupannya. Perkembangan ilmu pengetahuan dan teknologi mengakibatkan perubahan-perubahan dalam ilmu pendidikan.

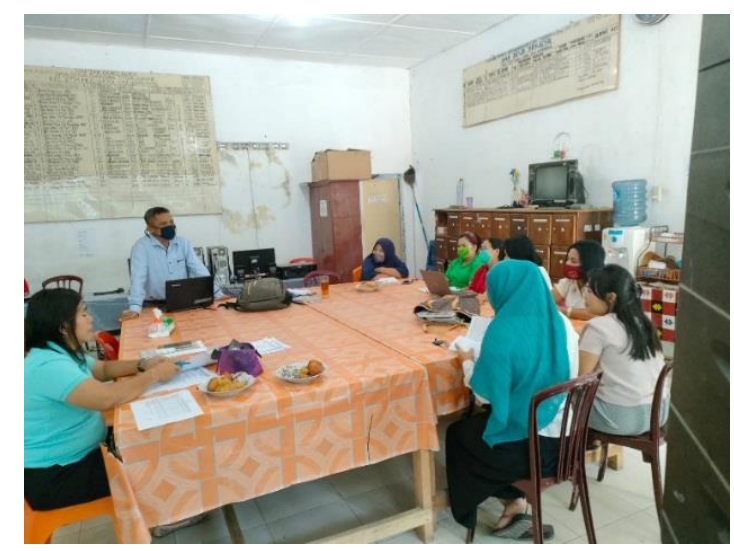

Gambar 8. Bimbingan terhadap Guru- Guru Bina Bangsa mengenai kurikulum dalam kondisi khusus/masa Pandemi

Penulis mengingatkan kepada Bapak/Ibu Guru supaya dalam memberikan pembelajaran kepada anak memilih topik yang urgent yang dibutuhkan siswa.sesuaikan kondisi dan kebutuhan siswa. Penulis mengatakan supaya materi disederhanakan dan dibuat vidio pembelajarannya pada setiap topik. Dengan adanya vidio ini ,bagi siswa yang kurang paham 
tentang materi yang diajarkan karena waktu terbatas dapat melihat kembali vidionya dirumah. Penulis mengingatkan Pada Guru-guru ini,kalau tidak mampu membuat vidio pembelajaran ; download dari Mbah Google. Buatlah penugasan sesuai dengan materi yang diajarkan.

\section{d. Peniadaan Jam Istirahat}

Jam istirahat tidak perlu diadakan. Seusai belajar pada gelombang pertama anak-anak dipulangkan untuk menghindari kontak antar siswa. Dibuat kesepakatan antara berbagai pihak terkait, sekolah, orang tua dan siswa bahwa setiap selesai pembelajaran anak-anak langsung pulang. Bagi yang melanggar, dikenakan sanksi secara tegas dari sekolah.

\section{e. Adanya kesepakatan antara komite sekolah, kepala sekolah dan pemerintah daerah}

Kesepakatan ini sangat diperlukan untuk melihat situasi dan perkembangan yang ada terutama Satgas Covid-19 yang mengetahui pergerakan Covid-19 di daerahnya. Pemerintah daerah membuat aturan yang tegas dalam menjalankan protokol kesehatan. Kesepakatan antara sekolah, orang tua dan anak sendiri sangat perlu untuk meningkatkan kedisiplinan sesuai protokol kesehatan dan melihat situasi, kesiapan dan perkembangan kondisi yang ada.

Setelah dilakukan uji coba, perlu dilakukan evaluasi, dengan melihat perkembangan yang ada; kalau bertambah mungkin perlu dilakukan penghentian pembelajaran tatap muka. Dan, khusus bagi sekolah berasrama (boarding school), sebelum masuk asrama para siswa benar-benar dites sesuai standar penanganan Covid-19. Kalau sudah masuk asrama, anak-anak dilarang keluar masuk asrama secara bebas. Semoga pendidikan Indonesia semakin jaya dan bermartabat.

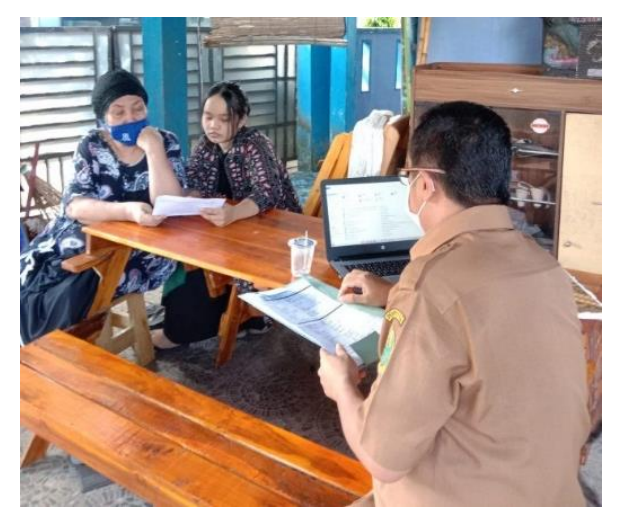

\section{Gambar 10.Kunjungan salah satu Guru kerumah orang tua Siswa}

Bapak Rahmad Muliadi S.Pd, yang merupakan Guru BK di SMAN Gunung Meriah melaksanakan kunjungan kerumah orang tua siswa. Bapak ini juga melaporkan kondisi belajar siswa dan hasil belajarnya.Bapak ini mengatakan ada penurunan semangat belajar dan nilai siswa.Ibu ini mengatakan; supaya pembelajarannya jangan Daring-daring saja Pak,habis paket,maunya pak dibuatlah tatap mukanya. Sebentarpun jadi pak ! biar tertib anak ini.kami enggak terawasi kami anak ini pak.keladangnya kami imbuh ibu ini .

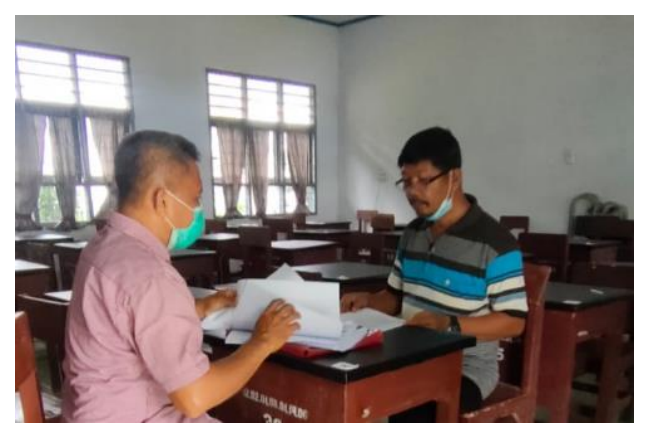

Gambar 12. Berdiskusi dengan pimpinan sekolah tentang kondisi dan hasil belajar anak.

Penurunan semangat belajar anak terjadi secara keseluruhan ,kata Pak Tompul.Pak tompul mengatakan semangat belajar anak yang menurun drastis.Anak sebagaian tidak mengerjakan tugas dengan berbagai alasan.Bapak ini mengatakan: Sebagian anak terpaksa 
kami tahan Raportnya pada semester ini pak,karena tidak mengerjakan tugas. Para Bapak/Ibu Guru kita ini pak sebagian menurun kinerjanya,kata beliau.Bahkan sering sebagian Bapak Ibu Guru tidak datang kesekolah.Dalam proses pembelajaran Bapak ini melaporkan memberikan penugasan melalui WA Group. Berbeda Binaan penulis di sekolah swasta ,para Bapak Ibu/Guru selalu datang kesekolah.

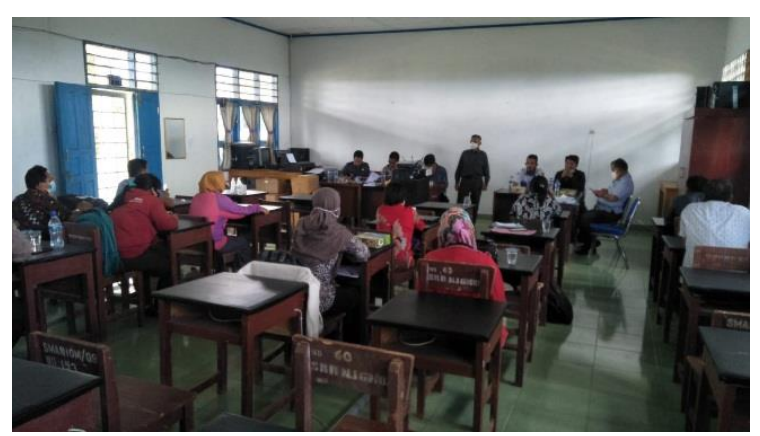

Gambar 13. Rapat dengan komite sekolah

Dalam rapat ini dibicarakan tentang pembelajaran anak disekolah.Secara umum mengeluhkan pembelajaran daring.Para orangtua menginginkan pembelajaran tatap muka.Persoalannya adalah pemerintah melarang pembelajaran Tatap Muka.Inilah dibicarakan teknisnya bagaimana agar tidak bertentangan dengan aturan pemerintahan.

Tabel 1. Evaluasi

\begin{tabular}{|l|l|l|l|l|}
\hline NO & Konsep & Pembelajaran Daring & Pembelajaran Daluta & Ket. \\
\hline 1 & Mengerjakan Tugas/PR & 1 & 3 & \\
\hline 2 & Disiplin siswa & 1 & 3 & \\
\hline 3 & Penguasaan Materi & 1 & 3 & \\
\hline 4 & Pembinaan Karakter pada orang & 1 & 3 & \\
\hline 5 & $\begin{array}{l}\text { Penghormatan } \\
\text { tua }\end{array}$ & 1 & 3 & \\
\hline 6 & Kepemimpinan & 1 & 3 & \\
\hline 7 & Bekerjasama/Kolaborasi & 3 & \\
\hline 8 & Kemampuan berpikir kritis & 1 & 3 & \\
\hline 9 & Kreatifitas dan Inovasi & 1 & 3 & \\
\hline 10 & $\begin{array}{l}\text { Mengakses } \\
\text { menganalisis informasi }\end{array}$ & 1 & 3 & \\
\hline
\end{tabular}

Ket : 1. Kurang memenuhi

2. memenuhi

3. sangat memenuhi

Evaluasi ini didapat dari wawancara dengan Guru dengan siswa,Guru dengan Orang tua dan Selanjutnya Penulis dengan Guru ,pimpinan sekolah, siswa dan orang Tua.Dari tabel ini dapat kita lihat; dari sepuluh konsep yang dievaluasi ,dinominasi Oleh DALUTA .Berarti DALUTA merupakan solusi pembelajaran masa Pandemi.

A. Kendala- Kendala yang Dihadapi

a. Ketakutan Kepala sekolah

Kepala sekolah menjadikan situasi ini beban.Program ini pasti tidak seluruhnya didukung,ada juga tidak berkenan yang menjadi boomerang bagi kepala sekolah karena dianggap melanggar peraturan.Penulis sebagai pengawas pembina tetap mesupport pimpinan sekolah 


\section{b. Pembelajaran Menggunakan Baju Biasa}

Pembelajaran dilaksanakan menggunakan baju biasa,untuk menghindari para insan pers ,supaya tidak menjadi pemberitaan.Ini merupakan kebijakan pelaksanaan pendidikan demi anak bangsa

c. Profesionalisme Guru

Sebagian Guru pengajarannya masih bergaya lama.Belum bisa merancang pembelajaran dengan menggunakan infokus dan membuat vidio pembelajaran ,maka pada perkembangan selanjutnya diadakan pelatihan oleh sekolah yang dianggarkan dari BOSS.

d. Sarana dan prasarana

Pembelajaran yang singkat dikelas,memaksa siswa dan Guru mengadakan pembelajaran cepat dengan menggunakan IT. Persoalan nya adalah sarana sekolah belum mencukupi dan begitu juga siswa.Sarana juga dianggarkan dalam BOSS.

\section{KESIMPULAN}

Proses pembelajaran yang dilaksanakan sebaiknya memberhasilkan siswa. Pembelajaran efektif, jikalau tercapai tujuan pembelajaran. Pembelajaran selama pandemi yang dilaksanakan secara daring, kurang efektif memberhasilkan siswa bahkan terjadi hilangnya semangat belajar siswa.Untuk itu sebaiknya dilaksanakan pembelajaran yang menggabungkan pembelajaran Daring, Luring dan Tatap Muka Terbatas. Pembelajaran Tatap Muka dilaksanakan dengan Pembelajaran Tatap Muka(PTM) Terbatas, yang memegang teguh protokol kesehatan.

\section{DAFTAR PUSTAKA}

Asmuni, Problematika Pembelajaran Daring di Masa Pandemi Covid-19 dan Solusi Pemecahannya SMA Negeri 1 Selong, Kabupaten Lombok Timur Corresponding Author from http://sosial.unmermadiun.ac.id/index.php/sosial/article/view/222261

Ali sadikin dkk Pembelajaran Daring di Tengah Wabah Covid-19 from https://onlinejournal.unja.ac.id/biodik

Hidayah, A. A. F., Al Adawiyah, R., \& Mahanani, P. A. R. (2020). Efektivitas Pembelajaran Daring di Masa Pandemi Covid 19. JURNAL SOSIAL :Jurnal Penelitian Ilmu-Ilmu Sosial, 21(September),

Keputusan Bersama Menteri Pendidikan dan Kebudayaan, Menteri Agama, Menteri Kesehatan dan Menteri Dalam Negeri No. 01/KB/2021, No. 516 Tahun 2020, No. HK.03.01/Menkes/363/2020, dan No. 440-882 tentang Panduan Penyelenggaraan Pembelajaran pada Tahun Ajaran 2020/2021 dan Tahun Akademik 2020/2021 di masa Covid-19. from https://online-journal.unja.ac.id/biodik

Lia Titi Prawanti dan Woro Sumarni (2020 ).Kendala pembelajaran Daring selama Pandemi Covid-19, makalah 2020 from UNNES http://proceeding.unnes.ac.id

Rahmadani, w. (2017). analisis faktor belajar biologi siswa materi bioteknologi di SMA Negeri sekota Medan. Pendidikan Biologi 279-285

Suciyati, M. (2018). hubungan Minat Belajar dengan Hasil Belajar Matematika pada Siswa Kelas V SD Negeri 04 Sila. Pendidikan MIPA 142- 149

Tutik Rachmawati. (2015). Teori Belajar dan Proses Pembelajaran yang Mendidik,Gava Media. Wasis D.dwiwogo. (2017). Pembelajaran Berbasis Blended Learning. Rajawali Pers

Mustakim, M. (2020). Efektivitas Pembelajaran Daring Menggunakan Media Online Selama Pandemi Covid-19 Pada Mata Pelajaran Matematika. Al Asma : Journal of Islamic Education, 2(1), 1. from https://doi.org/10.24252/asma.v2i1.13646

Sri Teguh Waluyo. (2020). Blended Learning untuk pelatihan vokasi. PT Srikandi Empat Widya Utama. 